\section{Australian Journal of \\ Crop Science}

AJCS 11(03):284-289 (2017)

doi: 10.21475/ajcs.17.11.03.pne363
ISSN:1835-2707

\title{
Response of horticultural crops to application of bioprotector and biological control of Ralstonia wilt in Brazilian Ultisol
}

\author{
Newton Pereira Stamford, Leandro Reis Costa Santos, Adriana Bezerra dos Santos, Kathiane \\ Rodrigues de Souza, Wagner da Silva Oliveira, Emmanuella Vila Nova da Silva
}

Department of Agronomy, University Federal Rural of Pernambuco, 52.171-900, Recife, Pernambuco, Brazil

\begin{abstract}
The production of biofertilizers from rocks is an economic process that increases nutrients for plant nutrition and reduces environmental pollution. The aim of the study was to evaluate the effectiveness of the bioprotector from phosphate and potassium rocks mixed with an earthworm compound inoculated with free-living diazotrophic bacteria (Beijerinckia indica) and fungus containing chitosan (Cunninghamella elegans) on the characteristics of tomatoes, peppers and green peppers inoculated and noninoculated with the wilt bacteria Ralstonia solanacearum. The fertilization treatments were: bioprotector applied at the 50\% recommended rate $-\mathrm{RR}\left(\mathrm{NPKP}_{50}\right), 100 \% \mathrm{RR}\left(\mathrm{NPKP}_{100}\right)$ and $150 \% \mathrm{RR}\left(\mathrm{NPKP}_{150}\right)$; soluble fertilizers applied alone at the recommended rate $\mathrm{RR}\left(\mathrm{NPKF}_{100}\right)$, with antibiotic $\left(\mathrm{NPKF}_{100}+\mathrm{ant}\right)$ and with crustaceous chitosan $\left(\mathrm{NPKF} \mathrm{F}_{100}+\mathrm{C}\right)$. A control treatment with earthworm compound $\left(20 \mathrm{t} \mathrm{ha}^{-1}\right)$ was used for comparative purposes. The best results for all horticultural plants were obtained with the bioprotector (NPKP) applied at the highest rate (150\% RR) and with the soluble fertilizer (NPKF) at the recommended rate for plants not inoculated with Ralstonia solanacearum. With regard to the effect of the bioprotector in the control of Ralstonia solanacearum, a different response for the horticultural crops with peppers revealed normal growth when inoculated with the pathogenic bacteria, and all of the tomato plants with soluble fertilizer alone died after pathogen addition. Soluble fertilizer with the addition of antibiotic and crustaceous chitosan protected green peppers and peppers against $R$. solanacearum, particularly when using chitosan. The bioprotector (NPKP) appears to be an alternative to soluble fertilizer.
\end{abstract}

Keywords: Earthworm compost; fungi chitosan; nitrogen fixation; organic fertilizer; phosphate and potassic rocks; plant protection Abbreviations: NPKB_biofertilizer with NPK nutrients; NPKF_soluble mineral fertilizers with NPK nutrients; NPKP_bioprotector with NPK nutrients; RR_Recommended Rate.

\section{Introduction}

The tomato (Lycopersicon esculentum Mill) is a horticultural plant of the family Solanaceae that has great economic and social importance; however, it is very sensitive to disease, specifically the bacterial wilt Ralstonia solanacearum (Costa et al., 2007). Green peppers (Capsicum annuum L.), which originated on the American continent, may be cultivated throughout the entire year, particularly in hot climate regions. It is an important crop that is considered one of the ten most preferred plants by international consumers but is vulnerable to many diseases and can be attacked by wilt bacterial disease $R$. solanacearum (Santana et al., 2014). The pepper (Capsicum frutescens L.) is another horticultural plant originating from tropical regions that is adaptable, and the fruits are considered a source of vitamins A and C. It is specifically used for industrial purposes (Zhu et al., 2005), and its resistance to bacterial wilt is specifically unknown.

$R$. solanacearum is a gram-negative pathogenic bacteria that promotes one of the most serious diseases for many varieties of vegetables, including tomatoes, green peppers, peppers, potatoes and bananas (Hayward, 2000). This pathogenic bacteria attacks the roots during radicular growth via lenticels and mechanical damage (Hernández et al., 2005). Inside the plant, the bacteria colonize the xylem at a population level up to $10^{10}$ UFC (Unit Forming Colonies) per $\mathrm{cm}$ of stem (Von Bodman et al., 2003). Next, the bacteria invade the phloem and are flagellated, although its mobility in plants is limited (Tans-Kersten et al., 2001).

The demand of the consumer market for quantity and quality requires the use of culture systems with high productivity, and it is thus important to update our knowledge of plant nutrition and specific crop management. Fertilization should provide good physiological conditions and offer maximum resistance against plant pathogenic attack. Several studies have shown the importance of applying high rates of organic fertilizers to meet nutrient demands (Oliveira et al., 2004) and alternatively observe the development of vegetable crops and resistance to diseases (Berger et al., 2016).

A viable alternative that must be considered is the production of rock biofertilizers inoculated with the sulfur oxidizing bacteria Acidithiobacillus, which produces sulfuric acid (Stamford et al., 2008). The phosphate and potassic biofertilizers produced from rocks mixed with organic matter, such as earthworm compost enriched in $\mathrm{N}$ by inoculation with diazotrophic bacteria (Lima et al. 2010), has shown high efficiency when applied in different soils and crops (Stamford et al., 2006, 2007, 2008, 2014, 2015).

The role of microorganisms in the biological control protection of plants against diseases is of great importance, particularly with the role of chitosan, as this biopolymer has demonstrated great performance against diseases (Berger et al., 2013). 
The study aimed to evaluate the effectiveness of a bioprotector produced by inoculation with the diazotrophic bacteria Beijerinckia indica and Cunninghamella elegans fungi, containing chitosan in their cellular walls, to improve the characteristics and productivity of tomatoes, green peppers and peppers. This study also aimed to evaluate the resistance against the pathogenic bacteria Ralstonia solanacearum by comparing the biofertilizer and soluble fertilizer applied alone and in joint application with antibiotics and crustaceous chitosan.

\section{Results and Discussion}

\section{Characteristics in plants not inoculated with Ralstonia}

In interpreting the results of the height of the tomato plants, no significant difference between the analyzed treatments were observed (Fig. 1), although the bioprotector application in all rates showed greater responses. Similar results were obtained for green peppers in field conditions, improving the effects of the fertilization treatments (Santana et al., 2014) and by Caixeta et al. (2014) during germination. The control treatment (earthworm compost $20 \mathrm{t} \mathrm{ha}^{-1}$ ) presented low values and were inferior to the bioprotector, particularly at higher rates, and the soluble fertilizer at the recommended rate. The differential response for peppers may be due to the first phase, as at the beginning of the sowing in trays, the plants showed low development compared with the other examined crops.

The results of the stem diameter (Fig. 2) displayed a similar response of obtained to height, and in tomato plants, the bioprotector treatments showed the best results, particularly when applied at higher rates, followed by a soluble fertilizer. For green peppers, the plants showed the same responses with no difference at all fertilization treatments except the control (earthworm compost - $2 \mathrm{t} \mathrm{ha}^{-1}$ ). The pepper plants showed a different response, with the best results observed when the bioprotector was applied at a higher rate $\left(\mathrm{NPKP}_{150}\right)$. The soluble fertilizer applied alone and the control treatment showed a lower stem diameter. These results were consistent with those obtained by Santana et al. (2014) when describing the interaction of organic and mineral fertilizers.

The results for the number of leaves in the tomato stem (Fig. 3) showed an effect of the bioprotector applied at the higher rate $\left(\mathrm{NPKP}_{150}\right)$ resulting in a higher number of leaves (15 leaves/plant). The other fertilization treatments did not present a significant difference between fertilizer treatments. Similar results were observed by Oliveira et al. (2004) using a biofertilizer derived from cow residues applied on the plant leaves of green peppers.

Green peppers and peppers did not show a significant bioprotector effect compared with soluble fertilizer applied alone or with the addition of an antibiotic and chitosan (Fig. 4). In the second harvest, the plant behavior showed a difference in tomatoes and the bioprotector (150\% RR) increased the shoot dry matter, while the control showed lower values. Green peppers with the bioprotector treatment at higher rates produced the best shoot dry matter values, while the control demonstrated lower values. These results demonstrated the potential of the biofertilizer as reported by Santana et al. (2014) for green peppers in field conditions and by Stamford et al. (2007) for yam-bean legume and (2008) for cowpeas in a Brazilian tableland acidic soil. For peppers, the fertilizer treatments showed the best responses but only differed compared to the control treatment with earthworm compost application.

\section{Shoot dry matter in plants inoculated with Ralstonia}

In the third harvest, when the plants were inoculated with the pathogenic bacteria $R$. solanacearum, the tomatoes continued to present higher shoot dry matter results when the bioprotector was applied at a higher rate (150\% RR). The soluble fertilizer applied alone and when mixed with antibiotic and chitosan showed lower results of shoots dry matter. For green peppers, the bioprotector at these rates and the soluble fertilizer with antibiotic and soluble fertilizer with chitosan promoted the best values of shoot dry matter (Fig. 4) and were superior to the control treatment (earthworm compost $20 \mathrm{t} \mathrm{ha}^{-1}$ ). The shoot dry matter for peppers promoted different behaviors, and higher values were observed when the fertilizer mixed with antibiotic and chitosan was applied, as well as the bioprotector at a higher rate $\left(\mathrm{NPKP}_{150}\right)$.

It was observed that the biofertilizers promoted higher results when an increased rate of biofertilizer was applied. Santos and Vidor (2003) used the "Agrobio" biofertilizer to obtain the best response to fertilization treatment only when measuring the characteristic shoot dry matter.

\section{Effect on biological control in plants inoculated with Ralstonia}

The horticultural plants presented different treatment effectiveness in the biological control of pathogenic bacteria $R$. solanacearum, applied after the third harvest and in plants evaluated in the following two weeks.

The tomato plants showed a significant response at 10 days after inoculation with the pathogenic bacteria. Plants with soluble fertilizer alone displayed dramatic symptoms of disease, and at 15 days, all the plants died. A slight response due to antibiotic and chitosan application was observed, but all the plants displayed a significant effect of pathogenic bacteria. Treatments with the bioprotector in the rates used revealed bacteriological control, and with $\mathrm{NPKP}_{150}$, the plants showed continued satisfactory growth with a significant increase in shoot dry matter.

The biological control for green peppers was relatively similar to the tomato plants with reference to the application of bioprotector at different rates, although among the treatments with soluble fertilizer, the addition of crustaceous chitosan increased dry matter production, and the plants showed specific resistance to pathogenic disease.

With regard to the effectiveness of the treatments in peppers, the response was different from the other crops and exhibited significant effectiveness, particularly in reference to the use of soluble fertilizer with the application of crustaceous chitosan. This treatment presented similar efficiency than the bioprotector applied at a higher rate $\left(\mathrm{NPKP}_{150}\right)$, and the plants continued to display satisfactory growth without symptoms of disease.

\section{Materials and Methods}

\section{Production of mixed biofertilizer and bioprotector}

The biofertilizer (BNPK) that was used as an alternative source of NPK nutrients for plants was produced using rock biofertilizers mixed with sulfur and Acidithiobacillus following the methodology of Stamford et al. (2007) and 


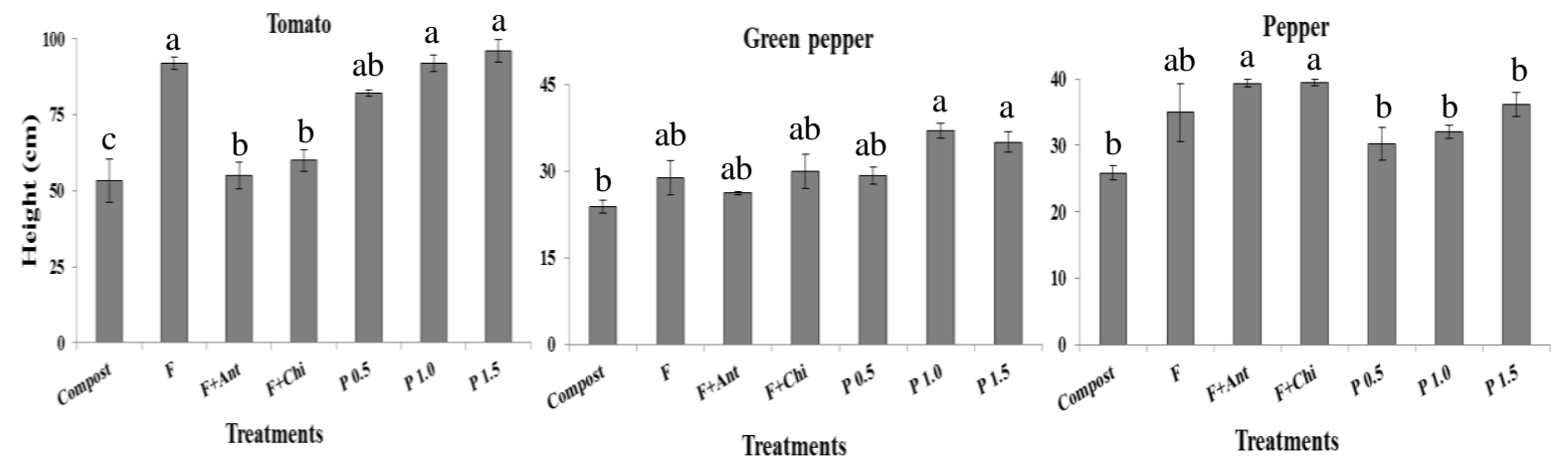

Fig 1. Height of tomato, green pepper and pepper in the second harvest (45 days) not inoculated with the wilt bacteria $R$. solanacearum, submitted to different fertilization treatments applying compost, soluble fertilizer alone $(\mathrm{F})$, and associated with antibiotic (F+ Ant) and with crustaceous chitosan (F+Chi), and protector $(\mathrm{P})$ at rates $50 \%(\mathrm{P} 0.5), 100 \%(\mathrm{P} 1.0)$ and $150 \%(\mathrm{P} 1.5)$. Means with different letters are significantly different $(\mathrm{P}<0.05)$ for the same horticultural plant.

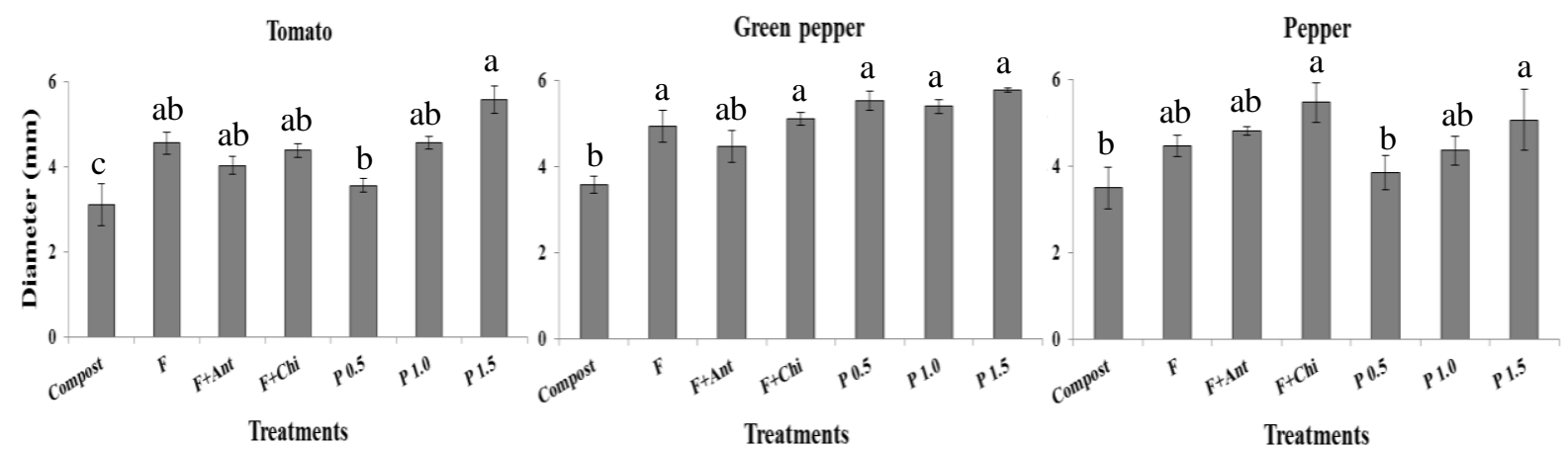

Fig 2. Stem diameter of tomato, green pepper and pepper in the second harvest (45 days) without inoculation with the wilt bacteria $R$. solanacearum, submitted to different fertilization treatments applying compost, soluble fertilizer alone $(\mathrm{F})$, and associated with antibiotic (F+ Ant) and with crustaceous chitosan (F+Chi), and protector (P) at rates 50\% (P 0.5), 100\% (P 1.0) and 150\% (P 1.5). Means with different letters are significantly different $(\mathrm{P}<0.05)$.

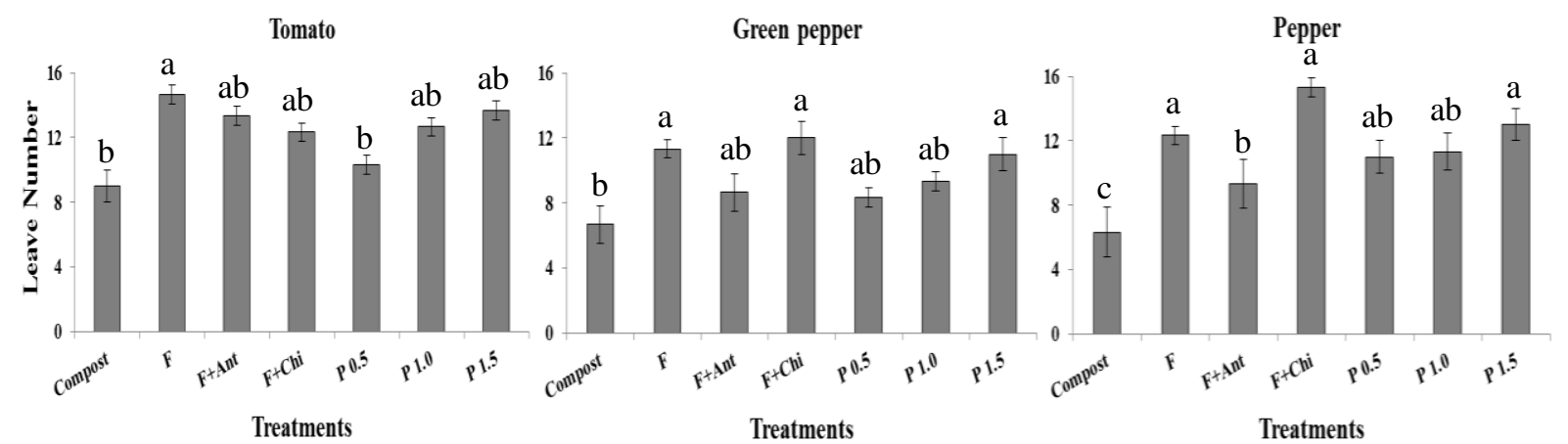

Fig 3. Number of leaves in tomato, green pepper and pepper in the second harvest (45 days) not inoculated with the wilt bacteria $R$. solanacearum, submitted to different fertilization treatments applying compost, soluble fertilizer alone $(\mathrm{F})$, and associated with antibiotic (F+ Ant) and with crustaceous chitosan (F+Chi), and protector (P) at rates 50\% (P 0.5), 100\% (P 1.0) and 150\% (P 1.5). Means with different letters are significantly different $(\mathrm{P}<0.05)$ for the same horticultural plant. 

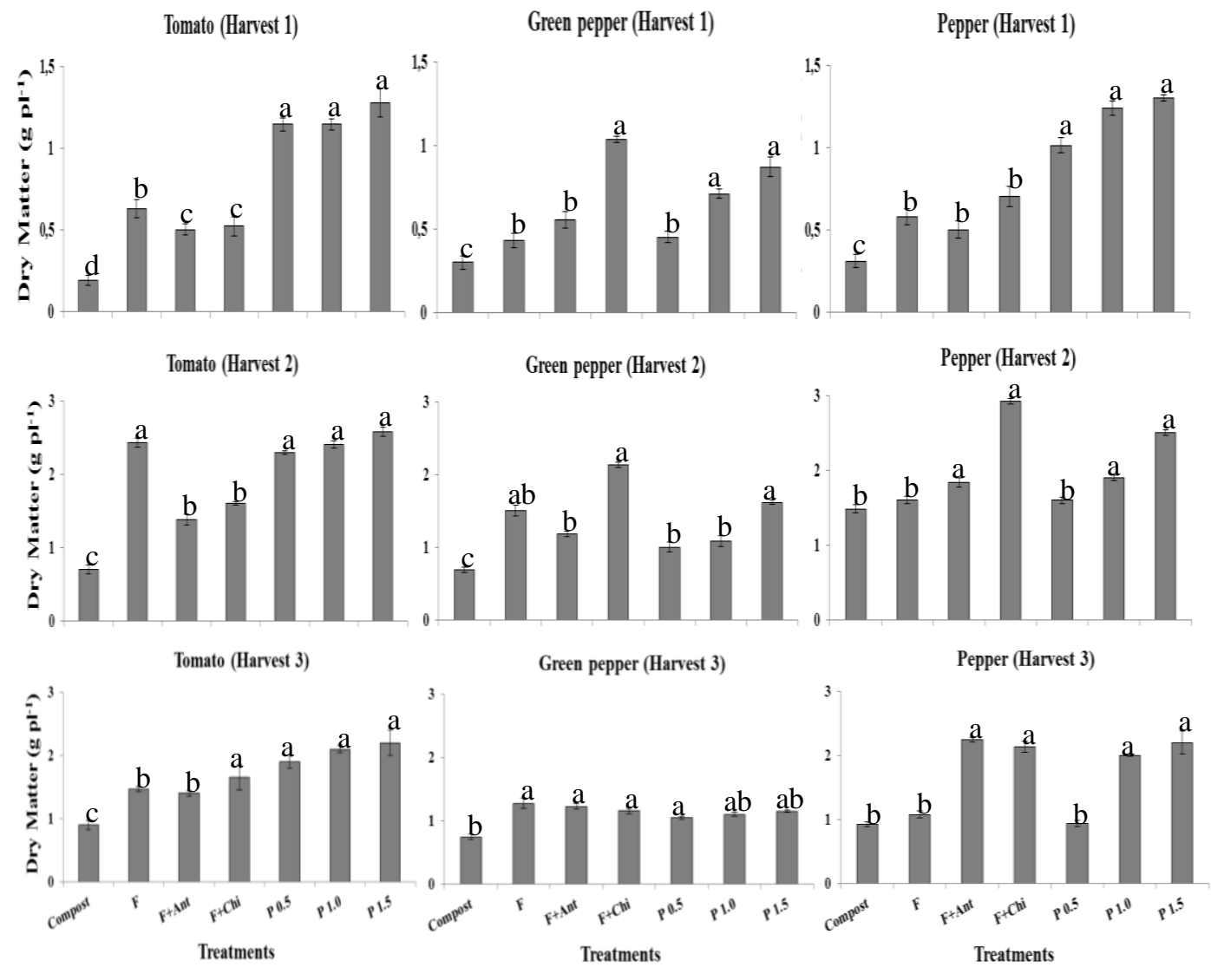

Fig 4. Shoot dry matter of tomato, green pepper and pepper with 30 days (harvest 1) and 45 days (harvest 2) not inoculated with the wilt bacteria $R$. solanacearum, submitted to different fertilization treatments applying compost, soluble fertilizer alone (F), and associated with antibiotic (F+Ant) and with crustaceous chitosan (F+Chi), and protector (P) at rates 50\% (P 0.5), 100\% (P 1.0) and $150 \%$ (P 1.5). At harvest 3 the plants were inoculated with $R$. solanacearum. Means with different letters are significantly different $(\mathrm{P}<0.05)$ for the same horticultural plant in the correspondent harvest.

mixed with organic matter (earthworm compost) enriched with $\mathrm{N}$ by inoculation with free-living diazotrophic bacteria (NFB 10001), in accordance with Lima et al. (2010). The bioprotector (NPKP) was produced by the addition of Cunninghamella elegans, a fungus that contains chitin and chitosan in its cell wall, to the biofertilizer (NPKB).

The results of the chemical analyses of the earthworm compost that was used to produce the NPK biofertilizer were: $\mathrm{pH}$ 7.95; organic carbon $\left(\mathrm{g} \mathrm{kg}^{-1}\right), 10.07$; total $\mathrm{N}\left(\mathrm{g} \mathrm{kg}^{-1}\right), 7.5$; total S $\left(\mathrm{g} \mathrm{kg}^{-1}\right), 1.98$; total $\mathrm{P}\left(\mathrm{g} \mathrm{kg}^{-1}\right), 1.1$.

Soluble fertilizer (NPKF) was produced by mixing ammonium sulfate $(20 \% \mathrm{~N})$, simple superphosphate $(20 \%$ $\left.\mathrm{P}_{2} \mathrm{O}_{5}\right)$ and potassium sulfate $\left(50 \% \mathrm{~K}_{2} \mathrm{O}\right)$, calculated based on soil analyses in accordance with the recommendations for banana (IPA, 2008). The fertilizer treatments were applied in the field at the moment of seedling transplantation.

\section{Site, soil and treatments}

The greenhouse experiment using soil from the district of Petrolina, Pernambuco, Brazil, classified as Ultisol Ustult dystrophic (Soil Survey Staff, 2014). The soil was chemically and physically analyzed using sample collected from the experimental area $(0-30 \mathrm{~cm}$ layer), and the results, using the methodology of Embrapa (2009) showed: $\mathrm{pH}\left(\mathrm{H}_{2} \mathrm{O}\right.$ 1.0:2.5) $=$ 5.6; total $\mathrm{N}=0.7 \mathrm{~g} \mathrm{~kg}^{-1}$, organic carbon $=6.5 \mathrm{~g} \mathrm{~kg}^{-1}$, available $\mathrm{P}=5.9 \mathrm{mg} \mathrm{dm}{ }^{-3}$; soluble $\mathrm{S}_{-} \mathrm{SO}_{4}{ }^{-2}=26 \mathrm{mg} \mathrm{dm}^{-3}$; exchangeable cations $\left(\mathrm{cmol}_{\mathrm{c}} \mathrm{dm}^{-3}\right): \mathrm{Ca}^{2+}=1.41 ; \mathrm{Mg}^{2+}=0.63$;
$\mathrm{K}^{+}=0.3$; global density $\left(\mathrm{g} \mathrm{cm}^{-3}\right) 1.67$; bulk density $\left(\mathrm{g} \mathrm{cm}^{-3}\right)$ 2.63 ; texture $\left(\mathrm{g} \mathrm{kg}^{-1}\right)$ sand $=788$; silt $=162$ and clay $=50$.

The experiment was performed in a factorial $(7 \times 2)$ with seven fertilization treatments, inoculated and non-inoculated with $R$. solanacearum, in a split plot design with four replicates. The fertilization treatments were bioprotector applied at the $50 \%$ recommended rate - RR $\left(\mathrm{NPKP}_{50}\right), 100 \%$ RR $\left(\mathrm{NPKP}_{100}\right)$ and $150 \%$ RR $\left(\mathrm{NPKP}_{150}\right)$; soluble fertilizers applied alone at the recommended rate $\mathrm{RR}\left(\mathrm{NPKF}_{100}\right)$, with antibiotic $\left(\mathrm{NPKF}_{100}+\mathrm{ant}\right)$ and with crustaceous chitosan $\left(\mathrm{NPKF}_{100}+\mathrm{C}\right)$. A control treatment with earthworm compound $\left(20 \mathrm{tha}^{-1}\right)$ was used for comparative purposes.

\section{Conduction of the experiment and pathogen inoculation}

The soluble fertilizer was applied alone and with antibiotic and crustaceous chitosan to observe the activity of the supplements against pathogenic bacteria because the soluble fertilizers alone was previously shown to be completely ineffective against $R$. solanacearum in tomato plants. All plants with soluble fertilizer died after 15 days when the plants were inoculated with the pathogenic bacteria.

In the first phase of the experiment, the plants were not inoculated with the phytopatogenic bacteria, and after 45 days of growth (after the third harvest), the bacteria $R$. solanacearum was inoculated as previously described by Schell (2000). 


\section{Plants cultivars and characteristics}

The horticultural plants (tomatoes - cv. IPA 6, green peppers - cv. all big, and peppers - cv. Malagueta) were cultivated in pots $(6 \mathrm{~L})$ containing $5 \mathrm{~kg}$ of soil, and the humidity was maintained at approximately $80 \%$ of maximum capacity by daily application of distilled water. The seeds were previously sown in plastic trays with 128 cells, maintained for 30 days, and then transplanted with 6 seedlings per pot. After one week, the plants were thinned and each pot consisted of 4 seedlings.

At 15 days after transplantation, samples were collected (one plant per pot), and the plant characteristics (height, stem diameter, fresh weight, number of leaves) were determined. The height of the plants was determined using measuring tape, and data of the stem diameter was determined using a caliper. At the same time, the antibiotic and crustaceous chitosan were added. The addition of antibiotic $\left(20 \mathrm{~mL} \mathrm{pot}^{-1}\right)$ consisted of a solution containing Erythromycin $\left(1 \mathrm{~g} \mathrm{dm}^{-3}\right)$, and the chitosan $\left(20 \mathrm{~mL}^{-1}\right)$ used a solution containing crustaceous chitosan (Sigma; $10 \mathrm{~g} \mathrm{dm}^{-3}$ ). After collection, the plant materials were placed in paper bags and dried in a forced circulation oven $\left(65-70{ }^{\circ} \mathrm{C}\right)$ to obtain constant weight for the determination of the dry matter.

For the three species, at 30 days and 45 days of plant growth, the same process to obtain the data of the second and third harvest was performed. Immediately after the third harvest, the plants were inoculated with the bacteria $R$. solanacearum as described by Stamford et al. (2016). Briefly, a cut was made in the stem using a sterilized stylet, and a solution $\left(10 \mathrm{~mL} \mathrm{pot}^{-1}\right)$ with pathogenic bacteria was added at $10^{8}$ CFU (Colony Forming Unit). Two weeks after inoculation, the plant characteristics were determined and the behavior was observed in reference to the pathogenic resistance.

\section{Statistical analyses}

The data were analyzed using the SAS statistic program (SAS Institute, 2011) version 10.2. ANOVA were performed and the means were compared using the Tukey test $(p \leq 0.05)$. The data were not transformed because it was not necessary to process the statistical analysis, and all the parameters analyzed were normally distributed. Visual observations of the biological control were not processed with statistical analysis.

\section{Conclusion}

The non-inoculated plants with the bioprotector promoted an increase in the characteristics of tomatoes and green peppers when applied at higher rates $\left(\mathrm{NPKP}_{150}\right)$. The best results for peppers were observed when the bioprotector $\left(\mathrm{NPKP}_{150}\right)$ and soluble fertilizer with addition of antibiotic $\left(\mathrm{NPKF}_{100}+\mathrm{Ant}\right)$ and chitosan $\left(\mathrm{NPKF}_{100}+\mathrm{C}\right)$ were applied. The NPKP could provide a better insight into nutrients efficiencies in the used soil. When the pathogen was applied, the best results were obtained with the bioprotector at a higher rate $\left(\mathrm{NPKP}_{150}\right)$. All the tomato plants with soluble fertilizer $\left(\mathrm{NPKF}_{100}\right)$ died after 15 days of $R$. solanacearum inoculation, and the application of antibiotics and crustaceous chitosan showed no interference. Green pepper plants with the bioprotector $\left(\mathrm{NPKP}_{150}\right)$ showed satisfactory growth, and a slight effect of chitosan application was observed. For peppers, this biopolymer was able to act in the biological control against $R$. solanacearum.

\section{Acknowledgments}

The authors are grateful to CNPq - Conselho Nacional de Desenvolvimento Científico e Tecnológico "Brazilian Scientific and Technological Development Council", FACEPE -Fundação de Amparo à Ciência e Tecnologia do Estado de Pernambuco "Foundation for the Support of Science and Technology of the State of Pernambuco, and CAPES - Coordenação de Aperfeiçoamento de Pessoal de Nível Superior "Coordination to the Improvement of Education Personnel", for the financial support and scholarships.

\section{References}

Berger LRR, Stamford NP, Wiladino LG, Laranjeira D, Lima MAB, Malheiros SMM, Oliveira WJ, Stamford TCM (2016) Cowpea resistance induced against Fusarium oxysporum f. sp. tracheiphilum by crustaceous chitosan and by biomass and chitosan obtained from Cunninghamella elegans. Biol Control. 92: 45-54.

Berger LRR, Stamford NP, Santos CERS, Freitas ADS, Franco LO, Stamford TCM (2013) Plant and soil characteristics affected by biofertilizers from rocks and organic matter inoculated with diazotrophic bacteria and fungi that produce chitosan. J Soil Sci Plant Nutr. 13: 592603.

Caixeta F, Von Pinho EVR, Guimarães RM, Pereira PHAR, Catão HCR (2014) Physiological and biochemical alterations during germination and storage of habanero pepper seeds. African J Agric Res. 9: 627-635.

Costa SB, Ferreira MASV, Lopes CA (2007) Pathogenic and molecular diversity of Ralstonia solanacearum in the Brazilian Amazonic Region. Braz Phytopathol. 32: 285 294.

Hayward A (2000) Ralstonia solanacearum- Encyclopedia microbiol 4. Academic Press, San Diego, California, USA.

Hernández Y, Marino N, Trujillo G, Urbina C (2005) Invasión de Ralstonia solanacearum en tejidos de tallos de tomate (Lycopersicon esculentum Mill). Rev Fac Agron. 22:185-194.

IPA - Instituto Agronômico de Pernambuco (2008) Recomendações de adubação para o estado de Pernambuco. Recife, Brazil.

Lima FS, Stamford NP, Sousa CS, Lira Junior MA, Malheiros SMM, Van Straaten P (2010) Earthworm compound and rock biofertilizer enriched in $\mathrm{N}$ by inoculation with free living diazotrophic bacteria. World J Microb Biot. 26: 1769-1775.

Oliveira AP, Paes RA, Souza A, Dornelas CSM, Silva RA (2004) Produção de pimentão em função da concentração de urina de vaca aplicada via foliar e da adubação com NPK. Rev Agropec Tecnica. 25: 37-43.

Santana R, Stamford NP, Santos CERS, Silva Junior S, Freitas ADS, Arnaud TMS (2014) Influence of bioprotector produced by interspecific microbial inoculation on green pepper characteristics and nutrient uptake. Global J Sci Frontier Res. 14: 7-14.

Santos Filho GN, Vidor C (2003) Solubilização de fosfatos por microrganismos na presença de fontes de carbono. Brazilian J Soil Sci. 24: 311-319.

SAS Institute (2011) The SAS 10.2 software, Statistical Analysis System for Windows. 478. In: Procedure guide for personal computer, Cary.

Schell M (2000) Control of virulence and pathogenicity genes of Ralstonia Solanacearum by an elaborate sensory network. Annu Rev Phytopathol. 38: 263-92. 
Stamford NP, Figueiredo MV, Silva Junior S, Freitas ADS, Santos CERS, Lira Junior MA (2015) Gypsum and sulfur with Acidithiobacillus and PK rock biofertilizer effects on soil salinity alleviation, cowpea biomass and nutrient status. Sci Hortic-Amsterdam. 79: 287-292.

Stamford NP, Silva Junior S, Santos CERS, Freitas ADS, Santos CMA, Arnaud TMS, Soares HR (2014) Yield of grape (Vitis labrusca cv. Isabel) and soil nutrients availability affected by biofertilizers with diazotrophic bacteria and fungi chitosan. Aust J Crop Sci. 8: 301-306.

Stamford NP, Santos CERS, Silva Junior S, Lira Junior MA, Figueiredo MVB (2008) Rock biofertilizers with Acidithiobacillus and rhizobia on cowpea nodulation and nutrients uptake in a tableland soil. World J Microb Biot. 24: 2061-2066.

Stamford NP, Santos PR, Santos CERS, Freitas ADS, Dias SHL, Lira Junior MA (2007) Agronomic effectiveness of biofertilizers with phosphate rock, sulfur and Acidithiobacillus in a Brazilian tableland acidic soil grown with yam bean. Bioresource Technol. 98: 1311-1318.

Stamford NP, Lima RA, Santos CERS, Dias SHL (2006) Rock biofertilizers with Acidithiobacillus on sugarcane yield and nutrient uptake in a Brazilian soil. Geomicrobiol J. 23: 261-265.
Tans-Kersten J, Huang H, Allen C (2001) Ralstonia solanacearum needs motility for invasive virulence on tomato. J Bacteriol. 183: 3597-3605.

Soil Survey Staff (2014) Keys to soil taxonomy, 12th ed. U.S. Department of Agriculture, Natural Resources Conservation Service, Washington, D.C.

USDA - United States Department of Agriculture. Natural Resources Conservation Service. (2014). Soil survey staff. Keys to Soil Taxonomy. 12a . ed. Washington, D.C. 372p.

Von Bodman, Dietz W, Coplin D (2003) Quorum sensing in plant-pathogenic bacteria. Annu Rev Phytopathol. 41: 455482.

Zhu JH, Li XL, Christie P, Li JL (2005) Environmental implications of low nitrogen use efficiency in excessively fertilized hot pepper (Capsicum frutescens L.) cropping systems. Agr Ecosyst Environ. 111:70-80. 